\title{
PUSAT KENDALI DAN EFIKASI-DIRI SEBAGAI PREDIKTOR TERHADAP PROKRASTINASI AKADEMIK MAHASISWA
}

\author{
Afiani Rizvi \\ Johana Endang Prawitasari \\ Heily Prajitno Soetjipto \\ Universitas Gadjah Mada
}

\begin{abstract}
INTISARI
Tujuan penelitian ini adalah mengetahui kemampuan prediksi efikasi-diri dan pusat kendali terhadap prokrastinasi akademik. Penelaahan alasanalasan prokrastinasi yang menghubungkan efikasi-diri dan pusat kendali dengan prokrastinasi akademik memperjelas dinamika psikologis kemunculan prokrastinasi akademik.

Subjek penelitian beriumlah 111 mahasiswa Fakultas Psikologi Univer sitas Gadjah Mada Metode angket dengan Skala Pusat Kendali, Skala Efikasi. diri dan Skala Prokrastinasi Akademik dipergunakan untuk memperoleh data.

Data penelitian dianalisis dengan menggunakan analisis Regresi Ganda dan Analisis Varian 2 Jalur. Hasil analisis Regresi Ganda menunjukkan bahwa kedua prodiktor dapat dipergunakan sebagai prediktor atas kemunculan prokrastinasi akademik, dengan nilai konglasi sebesar 0,44646 ( $p<0,001$ ). Dari hasil Analisis Varian 2 Jalur nilai rerata tertinggi prokrastinasi akademik terdapat pada sel kategori efikasi-diri rendah dan pusat kendali eksternal. Dengan demikian terbukti bahwa prokrastinasi akademik lebih besar kemungkinan muncul pada subjek mahasiswa dengan efikasi-diri rendah dan pusat kendali ekstemal.
\end{abstract}

Kata kunci : Pusat kendali, efikasi diri, prokrastinasi akademik

Afianl Rizvi, lahir pada 30 April 1970 di Ba likpapan, Kalimantan Timur, adalah alumnus Fakultas Psikologi LGM. Mempunyai minat pada kajian pengembangan SDM dan psikologi sosial.

Johana Endang Prawitasari, adalah dosen Fakultas Pslkologi UGM. Ph.D. dalam bidang Psikologi Klinis diperoleh dari University of Arizona, USA.

Helly Prafitno Soetjipto, dosen Fakultas Psikologi UGM dan Peneliti PPK UGM.

\section{PENGANTAR}

$\mathbf{M}$ enghadapi era globalisasi, Pasar Bebas ASEAN 2003 maupun Pasar Bebas Dunia 2020 berbagai upaya antisipasi telah dilakukan. Soeharto (1993) menyatakan bahwa Garis Besar Haluan Negara (GBHN) 1993 memberi amanat peningkatan mutu manusia dan masyarakat Indonesia selama kurun waktu Pembangunan Jangka Panjang (PJP) II. Salah satunya adalah peningkatan kualitas sumber daya manusia Indonesia. Upaya antisipasi ini sangat di- 
perlukan mengingat rendahnya mutu sumber daya manusia of Indonesia sebagaimana terungkap dalam data United Nations Development Programme (1991 - 1994). Data tersebut menyebutkan bahwa indeks Pengembangan Manusia Indonesia adalah 0,499-0,586. Angka tersebut tergolong dalam kategori rendah kurang dan berada dalarn peringkat 98 - 105 di antara 173 negara.

Dalam rangka peningkatan kualitas tersebut dicanangkanlah Gerakan Disiplin $\mathrm{Na-}$ sional oleh Presiden Soeharto, pada tanggal 20 Mei 1995 (REPUBLIKA, 22 Mei 1995). Salah satu aspek disiplin kerja adalah disiplin waktu. Pernanfaatan waktu yang ideal adalah efisiensi waktu dalam unjuk kerja (kinerja) pelaksanaan tugas. Kinerja yang efisien waktu, menunjukkan perilaku menghargai waktu. Salah satu bentuk ketidakdisiplinan dalam hal waktu ini banyak diperlihatkan oleh pegawai negeri, karyawan, sebagaimana yang dilaporkan pada penelitian berikut. Hasil penelitian mengungkapkan bahwa ketidak-disiplinan pada beberapa instansi pernerintah di kota-kota besar begi. u tinggi, mencapai $78 \%$ (TEMPO, September 1991b). Bentuk perilaku tidak disiplin waktu ini sangat merugikan pemakai jasa (masyarakat).

Perilaku tidak disiplin waktu (pernanfaatan waktu yang tidak etisien) berarti juga unjuk kerja (kinerja) yang buruk. Dampak lanjut dari buruknya kineria adalah rendahnya tingkat produktivitas. Dampak tidak disiplin waktu yang buruk lainnya adalah kerusakan mental dan etos kerja pada orang yang bersangkutan.

Upaya yang ditempuh untuk menanamkan disiplin dilaksanakan bersamaan dengan upaya peningkatan kualitas sumber daya manusia. Upaya ini lebih banyak bersitumpu pada duria pendidikan (terutama dalarm hal ini perguruan tinggi) sehingga tuntutan dan tanggung jawabnya begitu besar, namun sarana dan prasarananya terbatas.
Hanya sekitar 22\% lülusan SMTA berkesempatan melanjutkan ke perguruan-perguruan tinggi Indonesia (Laporan World Bank 1995). Kecilnya persentase yang dapat ter. tampung menunjukkan lambannya percepatan peningkatan kualitas sumber daya manusia Indonesia.

Salah satu penyebab dari semakin berkurangnya kesempatan pendidikan berkaitan dengan ketidakdisiplinan banyak pihak terhadap waktu. Tidak efisiennya peng. gunaan waktu belajaroleh mahasiswa di perguruan tinggi- mulumya masa studi melebihi kurun waktu baku yang disediakan -berakibat berkurangnya peluang bagi mahasiswa baru, dan memperbesar dana pen. didikan. Diperlukan upaya efisiensi waktu menempuh pendidikan di samping penambahan dan efektivitas pemanfaatan segala sarana prasarana dan sistem pendidikan.

Beberapa penelitian atas perilaku tidak disiplin waktu. yang dalam literatur ilmiah psikologi disebut dengan prokrastinasi (procrastination), menjadi masalah substansiat pada mahasiswa. Persentase mahasiswa yang mengalami prokrastinasi cukup tinggi dan cenderung meningkat seiring dengan lama waktu kuliah. Artinya, makin lama kuliah makin berat derajat kecenderungan prokrastinasinya (Shaffer, 1973: Solomon \& Pothblum, 1984).

Berdasarkan data Biro Administrasi Akademik dan Kemahasiswaan Universitas Gadjah Mada terdapat $11,3142 \%$ (atau 2804 mahasiswa) dari seluruh mahasiswa Universitas Gadjah Mada yang terdaftar pada semester ganjil tahun akademik 1994/1995 yang lebih dan 7 tahun terdaftar sebagai mahasiswa. Sejumlah 3,3934\%-nya (841 mahasiswa) kuliah lebih dari 10 tahun. Persentase pada mahasiswa Fakultas Psikologi UGM jauh lebih besar. Sekitar $38,5 \%$ telah melewati masa studi 7 tahun (data administrasi Fakultas Psikologi, tahun ajaran 1995-1996). Hasil pemeriksaan Inspektur 
Jendral Departemen Pendidikan dan Kebudayaan Republik Indonesia pada Fakultas Pasca Sarjana Universitas Gadjah Mada pada tahun 1991, untuk program S2 dengan masa studi 2,5 tahun terdapat $20 \%$ dari mahasiswanya yang lulus setelah lebih dari 7 tahun, atau $18 \%$-nya dengan masa studi lebih dari 4 tahun (TEMPO, Pebruari 1991 a).

\section{Prokrastinasi}

Istilah prokrastinasi pertama-tama dipergunakan oleh Brown \& Holtzman (1967) untuk menunjuk pada suatu kecenderungan menunda-nunda penyelesaian suatu tugas atau pekerjaan. Ellis \& Knaus (1977) menggambarkan prokrastinasi sebagai " $A$ failure to initiate or complete a task or activity by a predetermined time". Sedangkan Silver (dalam Green, 1982) berpendapat prokrastinasi lebih dari sekedar kecenderungan, melainkan suatu respon mengantisipasi tugas-tugas yang tidak disukai, atau karena tidak memadainya penguatan atau keyakinan yang tidak rasional yang menghambat kinerja. Akibatnya, kata Solomon \& Rothblum (1984), "... to the point of experiencing subjective discomfort. Prokrastinator sadar menghadapi tugas-tugas yang bermanfaat dan penting bagi dirinya (prioritas utama). dengan sengaja menunda secara berulang. ulang (kompulsif), hingga muncul perasaan cemas dan perasaan bersalah (Ferran, 1991).

Dari beberapa definisi yang telah dikemukakan di atas, istilah prokrastinasi yang digunakan dalam penelitian ini didetinisikan sebagai kegagalan seseorang dalam mengerjakan tugas berupa kecenderungan hingga tindakan menunda-nunda memulai kineria atau menyelesaikan sehingga menghambat kinerja dalam rentang waktu terbatas, yang akhirnya menimbulkan perasaan tidak enak (cemas) pada pelakunya.
Rothblum (dalam Kalechstein, 1989) menguraikan dua ciri prokrastinator sebagai memiliki kecenderungan (a) hampir selalu atau selalu meninggalkan tugas-tugas dan (b) hampir selalu atau selalu mengalami masalah karena tingkat kecemasan yang tinggi, berkaitan dengan tindakan menunda atau meninggalkan tugas tersebut.

Prokrastinasi dalam penelitian ini dibatasi pada prokrastinasi akademik: penundaan tugas-tugas akademis. Unsur-unsur prokrastinasi akademik terdiri dari enam area akademik (Solomon \& Rothblum, 1984) yaitu: a) Tugas mengarang. Meliputi penundaan melaksanakan kewajiban menulis makalah, laporan atau tugas mengarang lainnya. b) Belajar menghadapi ujian. Mencakup penundaan belajar untuk menghadapi ujian tengah semester, ujian akhir semesSer atau kuis-kuis lain. c) Membaca. Menunda membaca buku atau referensi yang berkaitan dengan tugas akademik yang diwajibkan. d) Kinerja tugas administratif. Penundaan mengerjakan dan menyelesaikan tugas-tugas administratif. Seperti menyalin catatan kuliah, mendaftarkan diri dalam presensi kehadiran, daftar peserta praktikum, dan lain-lain. e) Menghadiri pertemuan. Penundaan atau keterlambatan menghadiri kJliah, praktikum dan pertemuan-pertemuan lain dan f) Kinerja akademik secara keseIuruhan. Menunda kewajiban mengerjakan ałau menyelesaikan tugas-\{ugas akademik lainnya secara keseluruhan.

Prokrastinator memerlukan waktu yang lebih lama dari orang umumnya, pandangan yang tidak realistis pada keterbatasan kemampuan atau waktu. Mereka cenderung menggunakan waktu yang dimiliki untuk aktivitas yang bersifa! hiburan seperti: membaca (Koran, majalah atau buku cerita lainnya), jalan, ngobrol, mendengarkan musik, menonton film, minum atau makan makanan kecil (Kalechstein, dkk,; 1989). 
Dalam penelitian yang dilakukan ofeh Birner (1993) dikenali bahwa prokrastinator memiliki keraguan dan ketidakpastian dalam menentukan sikap dan perilaku. Pada umumnya prokrastinator mengalami perkembangan kepribadian yang kurang matang atau memiliki kesadaran diri yang tidak merata. Kondisi ini memaksa prokrastinator untuk mempertahankan diri dari impulsimpuis yang mendesak dan dari impuls keterpisahan.

Akibat negatif dari prokrastinasi akademik secara langsung antara lain: kerusakan kineria akademik, meliputi kebiasaan buruk dalam belajar, motivasi belajar rendah (Semb, Glick \& Spencer, 1979), bentuk kognisi yang irasional, obsesif dan kompulsif, rendahnya harga diri dan rasa percaya diri (Solomon \& Rothblum, 1984; Ferrari \& McCown, 1994). Prokrastinasi berakibat pua terhadap ateksi seperti depresi dan kecemasan yang tinggi. Akibat lainnya dapat berupa kegagalan fatal yang menyakitkan. Prokrastinator sendiri tidak senang akan sikap dan perbuatannya, tetapi mereka kesukaran untuk mengatasi dan cenderung selalu mengulanginya kembali (Burka \& Yuen, 1983).

Berdasarkan manfaat, Ferrari (1991) membagi prokrastinasi menjadi dua. Pertama, Prokrastinasi fungsional (Functionat procrastination), yaitu penundaan mengerjakan tugas dilakukan bertujuan memperoleh informasi yang lebih lengkap dan akurat. Sedangkan prokrastinasi yang tidak bertujuan, menimbulkan masalah atau berakibat jelek disebut prokrastinasi tidak fungsional (Distunctional procrastination). Pada penelitian ini prokrastinasi yang dimaksud adalah prokrastinasi tidak fungsional. Ada dua macam prokrastinasi tidak fungsional yaitu:

\section{a Prokrastinasi Pengambilan Keputusan (Decision procrastination): Penundaan}

membuat keputusan. Jenis prokrastinasi ini merupakan sebuah antesenden kognitif dalam menunda kinerja guna menghadapi situasi yang dipersepsikan penuh stres (Janis \& Mann dalam Ferrari, 1991a).

b. Prokrastinasi Pertuatan (Behavioral procrastination): Perilaku tampak (overtbehavior) prokrastinasi. Kecenderungan umum untuk menunda tugas sehari-hati. Kedua prokrastinasi ini terkadang dilakukan bersama-sama. Prokrastinasi perbuatan sering merupakan kelanjutan dari Prokrastinasi Pengambilan Keputusan.

Penelitian Pusat Konseling di Universitas California, Berkeley (Burka \& Yuen, 1982) membuktikan para prokrastinator memiliki masalah-masalah psikologis yang begitu kompleks antara lain pemberontakan terhadap aturan, tidak mampu bersikap tegas, ketakutan terhadap kegagalan atau kesuksesan, melihat tugas sebagai sesuatu yang aversif, perfeksionis, dan keyakinan yang berlebihan akan kompetensi dirinya.

Etiologi prokrastinasi diterangkan oleh Solomon \& Rothblum (1984) dengan membagi dalam tiga faktor kategori:

a. Takut gagal( $F$ baroffailure). Takut gagal atau motif menolak kegagalan, menu rut Weiner (1972), adalah suatu kecenderungan mengalami rasa bersalah apabila tidak dapat mencapai tujuan atau gagal.

b. Tidak menyukai tugas (Aver sive of the (ask). Berhubungan dengan perasaan negatif terhadap tugas atau pekerjaan yang dihadapi. Perasaan dibebani tugas yang terlalu berlebihan, ketidakpuasan, dan tidak senang melaksanakan tugas yang diberikan.

c. Faktor lain. Beberapa faktor lainnya yang dikelompokkan di sini, antara lain: sifat ketergantungan padd orang lain yang kua: dan banyak membutuhkan bantuan (Ferrari, 1994), pengambilan 
resiko yang berlebihan, sikap yang kurang tegas, sikap memberontak, dan kesukaran memilih keputusan. Bila dicermati faktor-faktor ini melingkupi pula faktor-faktor yang dikemukakan sebelumnya.

\section{Pusat Kendall dan Efikasi-dirl}

Upaya memahami komponen dinamika psikologis prokrastinasi dalam penelitian ini dipergunakan Pusat kendali dan Efikasi-diri. Pusat kendali berdasarkan konsep Rolter adalah konsep kepribadian yang memberi gambaran mengenai keyakinan seseorang dalam menentukan perilakunya (dalam Jung, 1978; Phares, 1978). Hal ini selaras dengan pengertian yang dikemukakan sebejumnya oleh Lefcourt (1982) dengan "kendali" sebagal "derajat ketika seseorang memandang peristiwa-peristiwa dalam hidupnya sebagai konsekuensi perbuatannya, sehingga ia dapat memilin apa yang dihar apkannya dengan mengendalikan perilaku. Sebaliknya ketika ia mamandang peristiwa-peristiwa tersebut tidak berhubungan dengan perilakunya, tetapi berhubungan dengan sesuatu yang berada di luar dirinya, maka peristiwa tidak dapat dikenda. likari".

Pengertian konsep tersebut dalam konsep Fotter (dalam Phares, 1978) dikenal dengan pusat kendali Internal dan pusat kendali eksternal:

a. Pusat kendali internal (internal locus of contro). Adanya hubungan antara perilaku dengan penguat (reinforcement) yang didapat, sebagai hubungan sebabakibat. Orang intemal merasa yakin bahwa dirinya memiliki kemampuan dan kebebasan menentukan perilakunya untuk mengendalikan penguat yang diterimanya.

b. Pusat kenadli eksternal (external locus of contron. Memandang peristiwa-pe- ristiwa yang terjadi, keberhasilan maupun kegagalan disebabkan oleh pengaruh kekuatan unsur-unsur fuar atau kondisi-kondisi yang tidak dapat dikendalikan atau tidak dikuasainya. Perilaku ditentukan bukan oleh dirinya. Periakunya dikendalikan oleh kekuatan eksternal seperti kesempatan, keberuntungan, nasib, kekuatan dari sistem sosial dan orang-orang lain yang berkuasa (Lefcourt, 1982).

Seperti telah dijelaskan sebelumnya, konsep mengenai pusat kendali yang digunakan Rotter memiliki empat konsep dasar. yaitu: a) Potensi perilaku (behavior potential, adalah setiap kemungkinan yang secara relatif muncul pada situasi tertentu, berkaitan dengan hasil yang diinginkan dalam kehidupan seseorang. b) Harapan (expectancy), merupakan suatu kemungkinan dari berbagai kejadian yang akan muncul dan dialami oleh seseorang. c) Nilai unsur penguat (reinforcement value), adalah pilihan terhadap berbagai kemungkinan penguatan atas hasi dari beberapa penguat hasil-hasil lainnya yang dapat muncul pada situasi serupa. d) Suasana psikologis adalah bentuk rangsangan baik secara internal maupun ekstemal yang diterima seseorang pada suatu saat, yang meningkatkarı atau menurunkan harapan terhadap munculnya has ii yang sangat diharapkan (Rotter dalam Jung, 1978; Rolter, Chance \& Phares dalam Lindzey \& Aronson, 1975).

Poten perilaku tergantung pada harapan akan kemampuan yang dimiliki, yang dipengaruhi oleh suasana psikologis tertentu, nilai penguat yang mengiringi perilaku dan nikai milik individu. Keterkaitan keempat konsep tersebut membentuk pusat kendali.

Pusat kendali adalah konsep yang secara Khusus berhubungan dengan harapan individu mengenai kemampuannya (pengharapan efikasi) untuk mengendalikan nilai pe nguat sesuai dengan situasi psikologisnya

PSIKOLOGIKA Nomor 3 Tahun \| 1997 
(Petri, 1980). Konsep pusat kendali bersifat kontinum; internai d satu kutub dan eksternal di sisi kutub lain. Seseorang diposisikan pada salah satu titik kutub yang ada di sepanjang garis kontinum tersebut (Phares dalam London \& Exner, 1978). Dalam situasi tertentu seseorang dapat berorientasi ke salah satu kutub konsep pusat kendali, misakya orientasi pada kutub internal, sedangkan pada situasi lain yang berbeda ia cenderung lebih eksternal. Seseorang tidak dapat digolongkan secara rnutlak internal atau eksternal, seperti pendapat Phares (London dan Exner, 1978), karena banyaknya faktor-faktor yang mempengaruhi pus at kendali seseorang.

Perbedaan pusat kendali pada seseorang ternyata dapat menimbulkan perbedaan pada aspek-aspek kepribadian yang lain. Hasil peneltian menunjukkan bahwa orientasi pusat kendali yang internal ternyata tebih banyak menirnbulkan pengaruh-pengaruh positif pada kepribadian, sebagaimana yang dikernukakan oleh Lao (dalam Munandar. 1980). Begitu pula menurut Pervin (1980) orang-orang internal lebih suka menentang pengaruh-pengaruh dari luar. Sedangkan orang eksternal tebih bersikap menerima (conform) terhadap pengaruh-pengaruh tersebut.

Rotter (dalam Weiner, 1972) dari beberapa hasil penelitian menyirnpulkan, perilaku merupakansuatu fungsi dari a) harapan (expectancy) individu bahwa tindakan yang diberikan akan rnenghasilkan imbalan (reward) berupa hadiah atau hukuman dan, b) nilai atau kepentingan (value or importance) yang dirasakan dari imbalan tadi. Diasumsikan orang bertindak adalah untuk rnemper. oleh hadiah dengan nilai yang tinggi (pres- tise, status) dan menghindari hukuman yang sangat tidak menyenangkan.

Berdasarkan pendapat Rottertersebut. Weiner(1972) mengajukan dua dimensi atribusi kausal dari perilaku berprestasi:

a. Lokasi penyebab internal atau eksternal (internal or external locus of control causality). Merupakan pusat kendali yang dimak-sud Fotter, dimensi pusat kendaIi internal dan eksternal sebagairnana telah dijelaskan di awal tulisan ini.

b. Ponyobab stabil/tidak penyebab secara temporal (temporally stable/unstable causality). Berkaitan dengan harapan. penyebab yang stabil dapat dipastikan perannya sehingga hasil yang diharapkan akan diperoleh. Sebaliknya sesuatu yang tidak stabil tidak begitu meyakinkan untuk diharapkan.

Dari dua dirnensi kausal terbentuk ernpat kombinasi unsur yang menentukan keberhasilan dan kegagalan seseorang dalarn perilaku kinerja menghadapi kesulitan kegiatan atau tugas (i hat gambar 1). Keempat unsur atribusi kausal perilaku berprestasi, yaitu unsur kemapuan/ability (InternalStabil), unsur usaha/effort (Internal-Tidak stabil), unsur kesukaran tugas (EksternalTidak stabil) dan unsur nasib (EksternalStabil) menggambarkan klasifikasi dari unsur penentu perilaku berprestasi menurut Weiner (1972). Partosuwido (1992) dalarn Skala Eksternal-Internal menambahkan unsur hingga berjumlah tujuh unsur. Unsur tersebut adalah kekuatan sendiri (internalStabil), unsur struktur sosial (EksternalStabil) dan unsur kekuasaan orang lain (Eksternal-Tldak stabil). 


\section{Gambar 1 \\ Atribusi Kausai Perilaku Berprestasi Klasifikasi Unsur Penentu Perliaku Berprestasi}

\begin{tabular}{|c|c|c|}
\hline & \multicolumn{2}{c|}{ PUSAT KENDALI } \\
KESTABILAN & INTERNAL & INTERNAL \\
\hline STABIL & Kemampuan & Kesukaran Tugas \\
\hline TIDAK STABIL & Usaha & Nasib \\
\hline
\end{tabular}

Sumber: Diterjemahkan dari Weiner, B. 1972 . Theories of Motivation, $356 \mathrm{p}$.

Orang internal, menurut penjelasan Spector (1982), menggantungkan diri pada ketrampllan (skili), kemampuan dli (ability) dan usaha (effort). Berdasarkan pemlkiran Ini terdapat gambaran bahwa orang-orang internal memiliki dorongan untuk berhasil dan prestasi sangat kuat sehingga dengan bekal kemampuan, mereka berusaha keras untuk meralh apa yang dinginkan secara efektit. Mereka mengambil peran aktif dalam mengatur, mengarahkan diri dan bertanggung jawab menentukan faktorpenguat ( $r$ inforcement) yang akan mereka terima. Sebaliknya orang eksternal, leblh banyak mengambil s/kap pasit dan kurang berusaha untuk memperoleh hasil atau faktor penguat (Scheibe dalam London \& Exner, 1978; Grasha, 1987; Doberty \& Ryderdalam Raha-yuningrum, 1993).

Rotter (dalam Weiner, 1972) menyatakan bahwa orang internal akan melath kemampuan dan kecakapan serta berusaha keras untuk memperoleh hasil yang diharapkan. Sebaliknya orang eksternal tidak terlalu pedull dengan kemampuaǹ dan kapasitas dirinya. Solomon dan Oberlander, (1974) menegaskan bahwa bila orang internal gagal, maka mereka akan merasa bertanggungiawab terhadap kegagalannya. Rasa tanggungjawab ini disertai pula slkap tidak mudah terpengaruh oleh lingkungannya. Orang internal akan berusaha keras walau ia harus berhadapan dan menentang Ingkungannya. Berbeda dengan orang internal, orang eksternat merasa tidak harus bertanggung jawab terhadap kegagalan yang dlalamlnya, karena hasil tersebut (kegagalan) bukantah akibat dari perbuatannya. Bersamaan itu pula mereka juga tidak merasa perbuatan dengan bekerja keras, akan membawa pengaruh pada keberhasllan atau hasil yang dlharapkan. Hal ini membawa pada sikap pasrah menerima (conform) terhadap pengaruh-pengaruh yang menerpa dirinya. Slkap tidak berdaya iri cermlnan dari perasaan ketidakberdayaannya yang membuat mereka tidak bertangguniawab terhadap hasil yang diterimanya (Solomon \& Oberlander, 1974; Pervin, 1980). Dalam suatu peneitian, Rotter (dalam Weiner, 1972) menyimpulkan bahwa untuk meneliti perilaku seseorang dari segi situasi belajar akan lebih efektlf bila mengaitkan keyaklnan orang tersebut dengan tugas dan situasi yang dihadapi. Penelitian pusat kendall pada mahasiswa memberikan gambaran serupa bahwa pusat kendali internal pada umumnya berkaitan dengan perilaku positif, sedangkan pusat kendal eksternal berkaitan dengan perilaku yang kurang mendukung keglatan 
belajar dengan perilaku negatif.

Komponen kepribadian keơua, efikasidiri, menu rut Bandura (1982) adalah proses kognitif yang mempengaruhi motivasi seseorang berperilaku. Seberapa baik seseorang dapat menentukan atau memastikan terpenuhinya motif mengarah pada tindakan yang diharapkan sesuai situasi yang dihadapi. Keyakinan akan seluruh kemampuan ini meliputi kepercayaan diri, kemampuan menyesuaikan diri, kapasitas kognitif, kecerdasan dan kapasitas bertindak pada situasi yang penuh tekanan, seperti yang dimaksud dengan Bandura (1986) dalam membahas efikasi-diri. Efikasi-diri itu akan berkembang berangsur-angsur secara terus-menerus sejalan dengan meningkatnya kemampuan dan bertambahnya pengalaman-pengaiaman yang berkaitan.

Lebih lanjut Bandura (1986), menekankan efikasi-diri pada komponen kepercayaan diri seseorang menghadapi situasi-situasi akan datang, yang tioak jelas dan tidak dapat diperkirakan.Senngkali situasi-situasi tersebut pen uh tekanan. Keyakinan dan kepercayaan ini menopang kemampuan dan memberikan landasan bagi seseorang untuk berusaha dengan tekun, ulet, menumbuhkan motivasi yang kuat dan keberanian menghadapi hambatan.

Berdasarkan rangkaian pendapat dari Bandura serta didukung para ahli lain, maka disımpulkan efikasi-dıri dalam penelitian inı sebagai proses kognitif berupa persepsi atau keyakinan akan seluruh kemampuan untuk memilih, mengaktifkan dan mengorganisasikan perilaku yang relevan dengan pelaksanaan tugas (kinerja) dalam situasi tertentu agar mencapai tujuan atau hasi yang dinginkan.

Efikasi-diri, menurut Bandura (1986), memiliki tiga (3) komponen yaitu: a) Peng. harapan hasil (outcome expectancy): Harapan akan kemungkinan hasil dari perilaku. b) Pengharapan elikasi (efficacy expect- ancy): Harapan atas inunculnya perilaku atau kinerja yang dipengaruhi oleh persepsi indiviou pada kemampuan kinerjanya berkaitan dengan hasil. c) Nilai hasil (outcome value): Nilai kebermaknaan atas hasil yang diperoleh individu. Nilai hasil yang sangat berarti mempengaruhi secara kual motif indiviou untuk memperolehnya kembali.

Bandura (1982) menjelaskan bahwa perbedaan derajat efikasi-diri dipengaruhi oleh beberapa faktor. Faktor-taktor tersebut adalah sebagai berikut:

a. Silat fugas yang dihadapi. Situasisituasi atau jenis tugas tertentu menuntut kinerja yang lebih sulit dan berat daripada situasi tugas yang lain.

b. Insentif eksternal. Insentif berupa hadiah (rewar d) yang diberikan oleh orang lain untuk merefleksikan keberhasilan seseorang dalam menguasai atau melaksanakan suatu tug as (competence contingent insentif. Misalnya pemberian pujian, status sosial (kebangsawanan, sarjana), materi (uang, hadiah) dan lainnya.

c. Status atau peran individu dalam ling. kungan. Derajat status sosial seseorang mempengaruhi penghargaan dari orang lain dan rasa percaya dirinya.

d. Informasi tentang kemampuan diri. Efikasi-diri seseorang akan meningka! alau menurun jika ia mendapat informasi yang positif atau negatif tentang diriпya. Informasi mengenai kemampuan seseorang dapat diperoleh melalui 4 (empat) sumber (Bandura, 1986), yaitu: 1) Hasil yang dicapai secara nyata (enactive attainment, 2) Pengalaman orang lain (vicarious experience), 3) Persuasi verbal (verbal persuation) dan 4) Keadaan fisiologis (physlological state).

Efikasi-diri yang kuat mendorong seseorang berusaha keras dan optimis memper- 
oleh hasil positif ateu keberhasilan. Orang yang lemah atau rendah efikasi-dirinya mempertihatkan sikap tidak berusaha keras, karena pesimis akan berhasil. Orang dengan efikasi-diri tinggi aktualisasi dirinya lebih optimal dibanding orang yang rendah efikasidirinya. Keyakinan dari efikasi-diri tersebut disertai dengan harapan untuk memperoleh rilai penguat (reinforcement) atau imbalan (reward) dengan mengendalikan perilakunya.

Kompleksitas kinerja akademik menyediakan prestasi disertai tingkat kesulitan yeng tinggi. Keadean ini berimplikasi pada munculnya bermacam-bermacam reaksi kinerja mahasiswa terhadap tugas akademik seperti reaksi kecemasan, menghindar, kesulitan berkonsentrasi, rajin atau prokrastinasi. Perbedaan reaksi terhadap kewajiban dan tugas akademik pada diri seseorang ofpengaruhi faktor kognitif sebagai mekanisme evaluatif pembentuk perilaku. Faktor kognitif yang turut mempengaruhi antera lain keyakinan atas kemampuan untuk mengerjakan tugas tertentu (etikasi-diri) serta keyakinan seseorang atas sumber penentu perilaku (pusat kendali).

Dinamika keterhubungen efikasi-diri dan pusat kendali terhadap penundaan kinerja akademik atau prokrastinasi akademik oiterangkan pada gambar 2.

\section{Gambar 2}

\section{Pusat Kendali, Efikasi-dirl dan Pengar uhnya Terhadap Prokrastinasi Akademik}

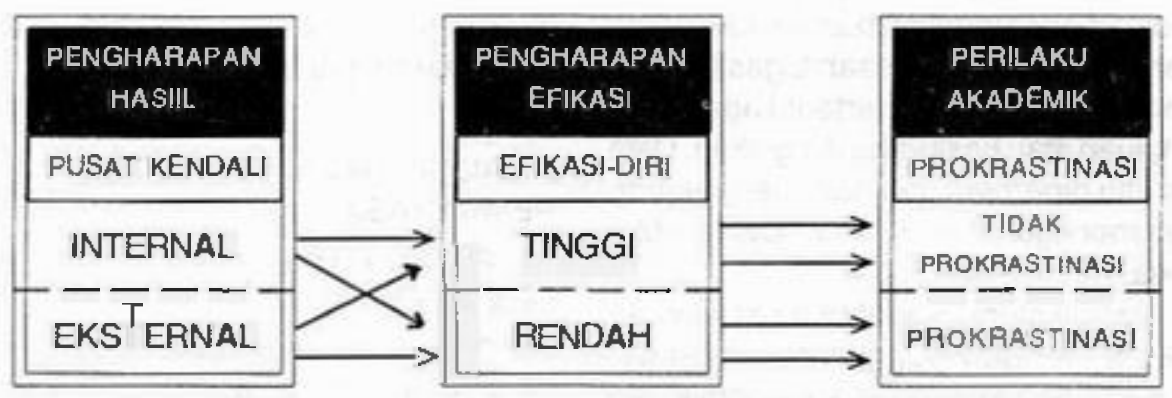

\section{HIPOTESIS}

Hipotesis mayor bahwa: Ada korelasi antara pusat kendali dan efikasi-diri terhadap prokrastinasi akademik. Subjek dengan etikasi-diri rendah dan pusat kendali eks. ternal cenderung lebih sering melakukan prokrastinasi akademik.

Bersamaan pula diajukan dua buah hipotesis minor untuk mendukung hipotesis mayor: a. Ada korelasi positif antara kecenderungan pusat kendali eksternal dengan prokrastinasi akademik. Semakin kuat kecenderungan pusat kendali eksternal makin besar kecenderungannya melakukan prokrastinasi akademik.

b. Ada korelasi negatif antara efikasi-diri dengan prokrastinasi akademik. Semakin rendah efikas-diri makin besar kecenderungannya melakukan prokrastinasi akademik. 


\section{METODE PENELITIAN}

Prediktor pertama adalah pusat kendali. Pusat kendali adalah derajat keyakinan seseorang terhadap sumber pengendalian perilaku (kinerja tugas akademik) yang berasal dari sumber internal berupa kekuatan yang dapat dikendalikan atau berasal dari sumber eksternal berupa kekuatan yang tidak dapat dikendalikan, berkaitan dengan hasil yang diperoleh orang tersebut berupa penguatan yang diterima (keberhasilan atau kegagalan akademik). Data ubahan ini diperoleh dari alat ukur Skala Pusat Kendali Mahasiswa. Data yang diperoleh dari skala ini berupa kecenderungan pada salah satu kutub pusat kendali, eksternal atau internal.

Prediktor kedua adalah efikasi-diri. Ef kasi-diri adalah proses kognitif berupa persepsi atau keyakinan akan seluruh kemampuan (akademik) untuk memilih. mengaktifkan dan mengorganisasikan perilaku yang relevan dengan pelaksanaan tugas (kinerja akademik) dalam situasi tertentu agar mencapai tujuan atau hasil yang diinginkan. Data efikasi-diri diperoleh dari hasil pengukuran dengan menggunakan Skala Efikasi-cjiri Mahasiswa.

Sebagai kriterium adalah prokrastina-si akademik dengan pengertian kecenderungan dan perilaku (kinerja akademik) seseorang berdasarkan keyakinan yang tidak rasional untuk menunda secara berulangulang pelaksanaan dan penyelesaian tugas yang akan dilaksanakan pada waktu lain, dengan disertai perasaan kecemasan sehingga menjadi hambatan kinerja yang kronis. Data derajat kecenderungan prokrastinasi diungkap dengan menggunakan Skala Prokrastinasi Akademik Mahasiswayang dikembangkan dari Procrastination Assessment Scale-Students (PASS) hasil penyusunan oleh Solomon dan Rothblum (1984). Skala ini terdiri dari dua (2) bagian. Data derajat kecenderungan prokrastinasi diper- oleh dari data pada bagian pertama skala: Skala bagian kedua memberikan data alasan-alasan prokrastinasi yang dilakukan responden.

Penelitian ini berdasarkan 111 subjek dari mahasiswa Fakultas Psikologi Universitas Gadjah Mada, D.I. Yogyakarta. Subjek penelitian adalah mahasiswa yang masih aktif kuliah pada semester ganjil tahun ajaran 1995-1996 dengan karakteristik yang dijadikan batasan subjek penelitian adalah sebagai berikut:

1. Mahasiswa yang telah menempuh studi selama 9 tahun (18 semester) hingga 2 tahun (4 semester). Ini dengan tujuan agar setiap angkatan dan kemungkinan dari prokrastinasi berimbang.

2. Pernah atau sedang mengikuti mata kuliah dengan disertai praktikum kuliah, penulisan makalah, laporan dan tugas akademik lainnya.

3. Aktif dalam perkuliahan pada saat pengambilan data penelitian ini.

\section{ANALISIS HASIL PENELITIAN DAN PEMBAHASAN}

Pertama, dari hasil komputasi data statistik Analisis Regresi Ganda dapat disimpulkan ternyata antara kedua prediktor secara bersama-sama (Pusat kendali dan Efikasi-diri) menunjukkan korelasi eksplisit yang sangat signifikan ( $r=0,45147 p<$ $0,001)$ dengan memberikan sumbangan efektif sebesar $20,383 \%$ terhadap variasi kriterium prokrastinasi. Masing-masing ubahan memberikan sumbangan yang berbeda arah, ubahan pusat kendali dan prokrastinasi akademik berkorelasi dengan taraf yang signifikan. Nitai korelasi ini meningkat dengan disertakannya efikasi-diri sebagai ubahan kedua. Peningkatan nilai korelasi mencapai hasil optimal dengan tarai yang sangat signifikan. Hasil ini menunjukkan bahwa prokrastinasi akademik mempunyai 
hubungan yang paling optimal apabila prediksi dilakukan oleh kedua ubahan secara bersamaan. Koefisien garis beta yang signifikan pada pusat kendali dan sangat signifikan pada efikasi-diri menegaskan bahwa pusat kendali dan efikasi-diri dapat digunakan sebagai prediktor.

Kedua, prediktor pusat kendali dan efikasi-diri memifiki hubungan yang kuat dengan prokrastinasi akademik. Perubahan variasi dari pusat kendali dan efikasi-diri berhubungan oiengan perubahan variasi prokrastinasi akademik. Kecenderungan prokrastinasi akademik seseorang dapat diketahui dengan melihat pada jenis pusat kendali dan tingkat efikasi-diri orang tersebut. Di antara kedua prediktor, tinggi rendahnya efikasi-diri mempunyai korelasi yang paling besar dan kuat terhadap kecenderungan prokrastinasi akademik.

Korelasi lugas pusat kendali terhadap prokrastinasi akademik sama dengan nilai Koefisien Garis Beta Pusat kendali yang berharga positif $(0,202702)$ dan nilai uji-t = $2,353(p<0,05$ ). Pusat kendali berbanding lurus atau linear dengan variasi kriterium prokrastinasi akadernik. Antara efikasi-diri dan prokrastinasi akademik koefisien garis beta berharga negatif $(-0,37237)$ dengan nilai uji-t $=-4,495(\mathrm{p}<0,001)$. Variasi efikasi-diri berbanding terbalik dengan prokrastinasi akademik. Arah dan kemampuan prediksi pusat kendali dan efikasi-diri terlihat dani harga koefisien garis beta pusat kendali yang positif dan harga efikasi-diri yang negatif.

Hasil dari Analis is varian dua jalur memperlihatkan ada perbedaan yang signifikan antara pusat kendali eksternal dan pusat kendali internal. Nilai rerata prokrastinasi akademik yang tertinggi terdapat pada kategori pusat kendali eksternal. Perbedaan antara kategori efikasi-diri tinggi dan efikasidiri rendah sangat signifikan, dan nilai rerata prokrastinasi akademik lebih tinggi pada kategori efikasi-diri rendah (lihat tabel 1).
Interaksi kedua prediktor pada sel-sel pusat kendali eksternal dan efikasi-diri rendah mempunyai nilai rerata derajat kecenderungan prokrastinasi akademik yang terbesar. Nilai rerata yang paling rendah adalah sel dari pasangan pusat kendali internal dan efikasi-ciri tinggi. Dengan demikian dapat disimpulkan bahwa perbandingan antara seseorang yang memiliki pusat kendali eksternal dan efikasi-diri rendah (selanjutnya disebut dengan Ekstemal-Rendah) kemungkinan melakukan prokrastinasi akademik sang at besar dibandingkan orang yang eksternal-tinggi, internal-tinggi dan intemal-rendah.

Orang internal-tinggi kemungkinan kecenderungan prokrastinasi akademiknya paling kecil.

Has i analisis varian dua jalur antara pusat kendali dan efikasi-diri dengan alasan pro-krastinasi menunjukkan perbedaan pada alasan kurang percaya diri yang berkorelasi dengan prokrastinasi akademik. Pusat kendali internal dan eksternal jelas berbeda pada alasan kecemasan dievaluasi, tidak asertif, suka memberontak, dan pengaruh teman yang berkoreasi dengan prokrastinasi akademik, kecuali takut keberhasilan tidak berkorelasi dengan prokrastinasi akademik. Efikasi-diri rendah dan tinggi terlihat perbedaannya secara nyata pada alasan malas yang berkorelasi dengan prokrastinasi akademik.

Korelasi yang terkuat dan terbesar adalah alasan malas $(6,0901, p<0,001)$. Korelasi yang terkecil nilainya dan paling kuat signifikansinya adalah alasan pengaruh teman $(3,9459, p<0,05)$. Alasan yang tidak berkorelasi alasan tidak mampu memanajemen waktu dan beban dan alasan takut berhasil.

Korelasi antara faktor alasan prokrastinasi dengan prokrastinasi akademik memperlihatkan faktor alasan tugas yang aversit, alasan pengaruh Iuar dan alasan takut 


\section{Tabel 1}

Nilai Rerata Prokrastinasl dalam Korelasinya pada Setiap Ubahan Pusat Kendall, Efikasl-diri dan Kombinasi Pusat kendali dan Efikasi-diri

\begin{tabular}{|c|c|c|c|}
\hline \multicolumn{2}{|c|}{$\begin{array}{c}\text { Berata } \\
\text { PFOKRASTINASI }\end{array}$} & \multicolumn{2}{|c|}{ EFIKASI-DIRI } \\
\hline$N=11$ & 203,51 & $\begin{array}{c}\text { Rendaho } \\
111 \text { Be N= } 51\end{array}$ & $\begin{array}{c}\text { Tinggi } \\
96,45 \mathrm{~N}=60\end{array}$ \\
\hline PUSAT & $\begin{array}{c}\text { Internal } \\
99,07 \\
N=55\end{array}$ & $\begin{array}{c}\text { I- R -:-: } \\
M 6,50 \\
(N=24)\end{array}$ & $\begin{array}{c}\text { 1. } T \\
9332 \\
\{N=31\}\end{array}$ \\
\hline KENDALI & $\begin{array}{c}\text { Ekmernal:: } \\
107.96 \\
N=5 e\end{array}$ & $\begin{array}{l}E-R 7 \\
116,50 \\
(N=27\rangle\end{array}$ & $\begin{array}{c}E-T \\
99,79 \\
\{N=29\}\end{array}$ \\
\hline
\end{tabular}

\begin{tabular}{|c|c|c|c|}
\hline \multicolumn{2}{|c|}{$\begin{array}{c}\text { Perata } \\
\text { PROKRASTINAS: }\end{array}$} & \multicolumn{2}{|c|}{ EFIKASI-DIRI } \\
\hline $\mathrm{N}=79$ & 104,67 & $\begin{array}{l}\text { Aendah s } \\
113,37 \mathrm{~N}=38\end{array}$ & $\begin{array}{c}\text { Tinggl } \\
9694 \quad \mathrm{~N}=41\end{array}$ \\
\hline PUSAT & $\begin{array}{c}\text { Internal } \\
97,95 \\
\mathrm{~N}=42\end{array}$ & $\begin{array}{l}1 . R 5 \\
106,89 \\
(N=19)\end{array}$ & $\begin{array}{c}\text { I. T } \\
90,57 \\
(N=23)\end{array}$ \\
\hline KENDALI & $\begin{array}{c}\text { Ekstimialn: } \\
\begin{array}{c}112,30 \\
N=37\end{array}\end{array}$ & $\begin{array}{l}\text { E-A-:* } \\
1 \mathrm{Bg4} \\
(N=19)\end{array}$ & $\begin{array}{c}E-T \\
704,33 \\
(N=18)\end{array}$ \\
\hline
\end{tabular}

Keterangan: $*$ mengalami prokrastinasi tingkat sedang dan rendah.

gagal berkorelasi secara signifikan terhadap prokrastinasi akademik. Orang Eksternal-Rendah atau Internal-Rendah cenderung menggunakan ketiga alasan ini.

Rerala sekor mentah skala pusat kendali, efikasi-diri dan prokrastınasi menunjukkan kecenderungan seluruh subjek penelitian memiliki pusat kendafi internal (rerata $=60,7117$ ), efikasi-diri tinggi (rerata $=$ $142,4054)$ dan derajat trekuensi prokrastinasi pada taraf sedang (rerata $=103,8108$ ).

Dengan diterimanya hipotesis mayordan kedua hipotesis minor, maka kecenderungan prokrastinasi dapat diprediksikan dengan menggunakan rumus persamaan sebagai berikut:

$$
\begin{aligned}
P A= & 149,188607+(0,393204 \times P K)+ \\
& (-0,488051 \times E d)+21,55991
\end{aligned}
$$

Keterangan:

PA : Prokrastinasi akademik

PK : Pusat kendali

Ed : efikasi-diri.
Dengan demikian, pusat kendali yang eksternal pada seseorang dan efikasi-diri yang rendah merupakan prediktor dari derajat kecenderungan prokrastinasi akademik yang tinggi. Orang yang efikasi-diri rendah. derajat kecenderungan prokrastinasi aka. demiknya jauh lebih tinggi daripada orang pusat kendali eksternal. Selanjutnya kecenderungan prokrastinasi akan lebih dapat diperkirakan lewat pengukuran efikasi-diri dari-pada pusat kendali. Namun penggunaan kedua prediktor secara bersama-sama akan lebih memperbesar kemampuan prediksi deraja: kecenderungan prokrastinasi akademik. Bahkan jauh lebih tajam dengan empat kombinasi kedua prediktor menjadikan empat kategori; Pusat kendali Internal-Efikasidir Tinggi (intemal-Tinggi), internal-Rendah, Eksternal-Tinggi dan Eksternal-Fendah. Kriteria kepribadian yang paling rendah kecenderungan prokrastinasi akademiknya adalah Internal-Tinggi (rerata $=90,57$ ), dan yang paling tinggi kecenderungan prokrastinasi 
akademiknya adalah Eksternal-Rendah (rerata $=119,84$ ).

Analisis tambahan yang dilakukan dengan menggunakan data dari Skala Prokrastinasi Akademik Mahasiswa bagian kedua (faktor alasan prokrastinasi akademik) mendukung hasil analisis keseluruhan penelitian ini. Secara keseluruhan prokrastinasi akademik berhubungan dengan kategori alasan Tugas Aversif, Pengaruh Eksternal dan Tar kut gagal. Kategori tugas aversif (alasan tugas yang tidak menyenangkan dan alasan malas) cenderung dipergunakan olehorang yang efikasi-dirinya rendah. Kategori pengaruh eksternal (alasan pengaruh teman dan alasan gangguan lingkungan) dipergunakan oleh orang eksternal, sedangkan kategori takut gagal (alasan kurang percaya diri, alasan perfeksionis dan alasan kecemasan dievaluasi) dipergunakan oleh orang Eksternal-Rendah.

\section{KESIMPULAN DAN SARAN}

Berdasarkan analisis data yang diperoleh, hasil penelitian menunjukkan diterimanya hipotesis mayor dan kedua hipotesis minor. Oleh karena itu pusat kendali dan efikași-diri sebagai komponen kognitif berhubungan dengan kinerja prokrastinafor. Bentuk korelasi tersebut positif pada pusat kendali dan negatif pada efikasi-diri. Kedua komponen kognitif (éfikasi-diri dan pusat kendali) dapat dipergunakan untuk memprediksi kemungkinan prokrastinasi.

Seseorang yang bermasalah dengan prokrastinasi akademik berdasarkan konsep éfikasi-diri dan pusat kendali merupakan

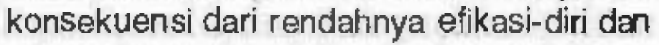
orientasi pusat kendali yang ekstemal. Komponen efikasi antara lain pengharapan efikasi yang rendah, pengharapan hasil yang rendah dan nilai hasil yang kurang bermakna menimbulkan keyakinan yang tidak rasional terhadap kemampuannya. Konsep dasarpu- sat kendali antara lain tidak memiliki potensi perilaku, rendahnya harapan, kurang berartinya nilai unsur penguat dan suasana psikologis yang tidak mendukung lebih besarnya kemungkinan kemunculan prokrastinasi.

Berdasarkan hasil penelitian yang diperoleh, penulis mengajukan beberapa saran sebagai berikut:

1. Para prokrastinator disarankan untuk meningkatkan efikasi-diri dan mengubah orientasi pusat kendali menjadi internal. Upaya meningkatkan efikasi-diri dan mengubah orientasi pusat kendali dapat dilakukan dengan meningkatkan kecakapan serta pengetahuannya berkaitan dengan iugas. Kemampuan yang memadai akan memperbes ar harapan efikasi. Perubahan yang terjadi pada efikasi-diri tidak ber diri sendin. Tingginya efikasi-diri mempermudah berubahnya orientasi pusat kendali.

2. Masyarakat luas perlu memperhatikan lingkungan atau kondisi yang melatarbelakangi munculnya prokrastinasi (dalam hal ini efikasi-diri yang rendah dan pusat kendafi eksternal) dengan membentuk mentalitas dan kepribadian yang memiliki pusat kendali internal serta efikasjdiri yang tinggi sejak dini. Struktur dan sistern sosial perlu dibenahi agar mendukung perkembangan mental psikologis manusia Indonesia yang sehat dan pribadi berkualitas.

Hal ini patut menjadi bahan pertimbangan bagi para praktisi yang banyak berhubungan dengan permasalahan prokrastinasi akademik dalam pembuatan kebilakan serta pengambilan keputusan yang tidak merugikan bagi semua pihak.

3. Pihak praktisi perguruan tinggi yang akan memberikan perlakuan (troatment) dapat menjadikan hasil penelitian ini sebagai pedoman dalam menyusun perlakuan untuk mahasiswa prokrastina- 
tor. Perlakuan dibuat dengan mengarah pada upaya peningkatan efikasi-diri dan mengubah orientasi pusat kendali eksiernal menjadi internal.

4. Pihak praktisi perguruan tinggi yang akan memberikan perlakuan (treatment) dapat menjadikan hasil penelitian ini sebagai pedoman dalam menyusun perlakuan untuk mahasiswa prokrastinator. Perfakuan dibuat dengan mengarah pa da upaya peningkatan efikasi-diri dan mengubah orientasi pusat kendali eksternal menjadi internal.

5. Para peneliti berikutnya yang akan mengungkap masalah prokrastinasi hendaknya menggunakan metode penelitian aksperimen dan observasi untuk memperoleh bukti mengenai hubungan kausalitas (sebab-akibat) dari kedua komponen kognitif terhadap prokrastinasi akademik. Eksperimen yang dilakukan dapat berupa sebuah me tode "token economic" sebagai upaya pendekatan perilaku unituk mengatasi prokrastinasi, atau pendekatan perilaku lainnya.

Hal lain yang periu dilakukan adalah pengembangan dan pengujian kembali Skala Prokrastinasi Akademik agar lebih sesuai dengan jenis tugas-tugas akademik sesuai kultur perguruan tinggi di Indonesia. Karena penelitian ini hanya dilakukan di sebuah universitas dan satu fakultas, maka masih ba. nyak ketidaksempumaan untuk dipergunakan di perguruan tinggi yang memiliki kultur pendidikan yang berbeda. Misalkan, tugasiugas terjemahan, resume jumal atau lainnya. Perbaikan pad a ska la ukur yang dipergunakan dalam penelitian, membantu diperolehnya data yang lebih handal, sehingga dapat menguji kesahihan dan kehandalan angket serta mempertajam pemahaman mengenai permasalahan prokrastinasi.
Peneliti hendaknya lebih memperthatikan faktor-faktor psikologis lain yang tu rut mempengaruhi munculnya prokrastinasi, misa|nya, kepercayaan diri (self-confidence), tipe kepribadian $\mathrm{A}$ dan $\mathrm{B}$, tingkat kecemasan, introvert-ekstrovert, kemampuan beradaptasi dan lainnya. Sebaiknya juga memasukkan faktor-faktor eksternal yang membenituk situasi kondusif sehingga memunculkan dan meningkatkan frekuensi prokrastinasi, misalkan gaya kepemimpinan. Selain itu juga dengan meneliti komponen-komponen atektif dan konatif sebagai prediktor yang akan melengkapi hasil penelitian ini dengan menggunakan komponen kognitif ini. Kornponen afektlf dan konatif yang disarankan antara lain: kecemasan. takut gagal, takut berhasil, tioak asertif, ketergantungan.

Penelitian dapal diperluas dengan mengungkap masing-masing faktor alasan prokrastinasi satu persatu. Faktor-faktor tersebut selanjutnya dibandingkan dengan karakteristik masing-masing jenis tugas akademik untuk menentukan permasalahan yang lebih spesifik dari masing-masing tugas akademik tersebut sehingga dapat dikenali jenis tugas mana yang memberikan sumbangan besar atas prokrastinasi akademik.

Penelitian yang disarankan hendaknya merefleksikan penelitian ini pada populasi alau subjek penelitian karaktenstik berbeda, misalkan pada mahasiswa dari fakultasfakultas ilmu pasti, perguruan tinggi swasta, atau pada akademı, institut dan lainnya. Penelitian akan lebih menambah khasanah ilmu apabila dilakukan pada subjek non mahasiswa seperti pada siswa SMTAatau para pegawai negeri dan karyawan. Dengan beraneka ragamnya subjek penelitian dan variatifnya jenis tugas akan semakin memperielas permasalahan prokrastinasi. $\sqsupset$ 


\section{DAFTAR PUSTAKA}

Bandura, 1982. Self-efficacy mechanism in human agency. Joumal American Psychologist.Vol. 37 No. 2, h. 122-147.

- 1986. Social Foundation of Thought and Action: A Social Cognitive Theory. Englewood Cliffs, NJ:: Prentice Hall.

Birner, L. 1993. Procrastination: Its role in transferences and counter transference. Psychoanalytic Review. Nol.80. No. 4 H.541-558.

Biro Administrasi Akademik dan Kemahasiswaan Universitas Gadjah Mada, Bagian Registrasi dan Statistik. BukuStatistik Mahasiswa Universitas Gadjah Mada tahun 1994. 23 Pebruari 1995.

Brown, WF. \&Holtzman, WP. 1967. Manual Surveys of Study Habits and Attitudes. New York: The Psychology Co.

Burka, J.B. \& Yuen, L.M. 1982. Mind games procrastination play. Psychology Today. January. Vol. 44 (p.32-34).

Burka, J.B. \& Yuen, L.M. 1983. Procrastination: Why you do it, what to do about it. Reading. MA: Addison-Wesley.

Ellis, A. \& Knaus, W.J. 1977. Overcoming Procrastination. New York: Institute for Rational Living.

Ferrari, J. R. 1991. Compulsive procrastination: Some self-report-ed characteristics. Psychological Reports. No. 68.h. 455-468.

- \& McCown, W. 1994. Procrastination tendencies among obssesive-compulsives and their relatives. Joumal of Clinjcal Psychology. Vol 50. No.2. h.162167.
- .1994. Dysfuctional procrastination and its relationship with self-esteem, interpersonal dependency, and self-defeating bahaviors. Personality and individuar Differences. No. 15.h. 539-544.

Green, L. 1982. Minority students self-control of procrastination. Joumal of Counseling Psychology. Vol. 29. (p.636-644).

Jung, J. 1978. Understanding Human Motivation. A Cognitive Approach. New York McMillan.

Kalechstein, P, Hocevar, D., Zimmer, J.W. \& Kalechstein, M. 1989. Procrastination over test preparation and test anxiety, dalam Schwarzer, R. (ed.). Advances in Test Anxiety Research. Vol. 6. Alblasserdam, Netherlands: Swets \& Zeitlinger Konters B. V. Lisse.

KOMPAS. 1989. Tajuk rencana, dalam $\mathrm{Ha}-$ rian UmUIn KOMPAS, 22 September 1989, Jakarta: PT. Kompas Media Nusantara.

Lefcourt, H.M. 1982. Locus of Control: Current trends in theory and research. Second edition. Hillsdale, New Jersey: Lawrence Eribaum Associates Publisher.

Lindzey, G. \& Aronson, E., 1975. The Handbook of Social Psychology. New Delhi: Amerind Publishing Co. Pvt. Lttd.

London, H. \& Exner, J. J.E. 1978. Dimension of Personality. New York: John Willey and Sons.Inc.

Partosuwido, S.R. 1992. Penyesuaian diri mahasiswa dalam kaitan dengan konsep diri, pusat control dan status perguruan tinggi. Disertasi, tidak diterbitkan Fakultas Pasca Sarjana, Universitas Gadjah Mada, Bulaksumur, Yogyakarta. 
Pervin, L.A. 1980. Personality: Theory, Assessment and Reserch. Third Edition. New York: Judith Wiley \& Sons, Inc.

Petri, H.L. 1980. Motivation: Theory and Research. Belmont Califomia: Woodsworth Publishing $\mathrm{Co}$.

Phares, 1978. Locus of Control.Dalam Dimension of Personality. London: Hand Exner. JR.

Republika. 1995. Disiplin nasional. Dalam (tajuk) Harian Umum REPUBLIKA, 22 Mei 1995. Jakarta: Yayasan Aboi Bangsa.

Semb, G., Glick, D.M. \& Spencer, R.E. 1979. Student withdrawals and delayed work patterns in self-paced psychology courses. Teaching Psychology. Vol.6. (p.23-25).

Shaffer, P.E. 1973. Academic progress of disadvantaged minority students: A 2Year study. Journal of College Student Personnel. Vol. 14 (p.41-46).

Solomon, \& Oberlander, 1974. Locus of Control in The Classroom. Dalam Cood, R.H. \& White, K Psysholagy Concept in the Classroom. New York Harper \& Row Publisher.

Solomon, L.J. \& Rothblum, E.D. 1984. Academic procrastination: frequency and cognitive-behavioral correlates. Journal of Counseling Psychology. Vol. 31. No.4. (p.503-509).

Spector, P.E. 1982. Behavior in Organizationas Function of Employee's Locus of Control.Psyshological Bulletin.

TEMPO. 1991 a Biar tua, tetap mahasiswa, dalam Majalah Mingguan TEMPO, 16 Pebruari 1991. Jakarta: PT. Grafiti Pers.

—. 19916 . Kemalasan para abdi dalam Majalah Mingguan TEMPO 28 September 1991. Jakarta: PT. Grafiti Pers.

United Nations Development Programme (1991). Human Development Feport 1991. New York: Oxford University Press.

World Bank. 1995. World Development Report 1994: Intrastructure development.

Weiner, B. 1972. Theory of Motwation: From Mechanism to Cognition. Chichago: Markhan Publishing, Co. 